\title{
BRPKM
}
Buletin Riset Psikologi dan Kesehatan Mental http://e-journal.unair.ac.id/index.php/BRPKM e-ISSN: 2776-1851

ARTIKEL PENELITIAN

\section{Career Adaptability dan Job Hopping Intention: Peran Career Satisfaction di Pekerja Generasi Y}

\author{
SEKAR HANUM PRIHANINGRUM \& HERISON PANDAPOTAN PURBA* \\ Fakultas Psikologi Universitas Airlangga
}

\begin{abstract}
ABSTRAK
Tujuan dari penelitian adalah memahami lebih dalam mengenai pengaruh antara career adaptability dan job hopping intention dengan career satisfaction (variabel mediator) yang terjadi pada karyawan generasi Y. Partisipan yang dibutuhkan peneliti adalah 103 karyawan yang bekerja di bawah dua tahun. Data dikumpulkan dengan cara menyebarkan kuesioner pada career adaptability scale (CAAS), career satisfaction scale, dan job hopping intention scale. Peneliti menguji analisis regresi linier dan uji sobel test. Hasil penelitian menunjukkan bahwa career adaptability memiliki pengaruh positif, tidak signifikan, dan memprediksi job hopping intention sebesar $0,02 \%\left(\mathrm{r}^{2}=0,002 ; \mathrm{p}>0,05\right)$. Hasil uji mediasi menunjukkan bahwa career satisfaction memiliki pengaruh mediasi pada hubungan career adaptability dengan job hopping intention karena signifikansi uji mediasi $\mathrm{p}<0,005$.
\end{abstract}

Kata kunci: career adaptability, job hopping intention

\begin{abstract}
This research has purposed due further determine the influence of career adaptability on the jobhopping intention with career satisfaction (mediator variable) for millennial employees. This research was conducted on 103 employees who worked under two years. Data collection was carried out using a Career Adapt-Ability Scale (CAAS), the career satisfaction scale, and the Job-Hopping Intention Scale. The data analysis technique was performed using linear regression analysis and mediation test through the Sobel Test. The results showed that career adaptability had a positive, insignificant effect, and predicted job-hopping intention of $0.02 \%\left(r^{2}=0.002 ; p>0.05\right)$. The results of the mediation test showed that career satisfaction had a full-mediated effect on the relationship between career adaptability and job-hopping intention because the significance of the mediation test was $p<0.005$.
\end{abstract}

Keywords: career adaptability, job hopping intention

Buletin Penelitian Psikologi dan Kesehatan Mental (BRPKM), 2021, Vol. 1(1), 883-891

*Alamat korespondensi: Fakultas Psikologi Universitas Airlangga, Kampus B Universitas Airlangga Jalan Airlangga 4-6 Surabaya 60286. Surel: herison.purba@psikologi.unair.ac.id

Naskah ini merupakan naskah dengan akses terbuka dibawah ketentuan the Creative Common Attribution License (CC-BY-4.0) (http://creativecommons.org/licenses/by/4.0), 
sehingga penggunaan, distribusi, reproduksi dalam media apapun atas artikel ini tidak dibatasi, selama sumber aslinya disitir dengan baik.

\section{PENDAHULUAN}

Generasi yang menjadi pekerja aktif saat ini, yaitu Generasi X dan Generasi Y. Saat ini dunia industri mengalami perkembangan secara pesat di mana Generasi Y menjadi generasi yang mendominasi di dunia industri (Luntungan dkk., 2014). Pekerja Generasi X merupakan pekerja yang lahir pada tahun 1960-1980 (Guha, 2010; Holyoke \& Larson, 2009). Saat ini karyawan Generasi X sebagai karyawan senior di lingkungan kerja dan menjabat di posisi manajerial yang menggantikan karyawan generasi baby boomer's yang sudah memasuki masa pensiun (Mahmoud dkk., 2021). Pekerja generasi Y merupakan pekerja kelahiran tahun 1980-2000 dan jumlah pekerja Generasi Y mendominasi di dunia industri, hal ini dapat dilihat data Badan Pusat Statistik pada tahun 2019 dan 2018 di mana jumlah pekerja Generasi Y tahun 2019 sebanyak 58.318.552 jiwa sedangkan pada tahun 2018 didapatkan jumlah pekerja tersebut sebanyak 57.435 .983 jiwa.

Generasi Y tentu saja berbeda dengan Generasi X, hal ini membawa perubahan pada dunia industri saat ini. Berikut ini aspek-aspek yang menjadi perbedaan di antara keduanya. Generasi X dikenal sebagai generasi yang self-directed, skeptis, dan juga mengutamakan work-life balance. Sedangkan menurut Anderson (2013 dalam Mahmoud dkk., 2021), Generasi Y memiliki orientasi bekerja yang berbeda, yaitu menginginkan pengakuan dan ingin bekerja di dunia kreatifitas. Generasi X memiliki karakteristik yaitu melakukan perpindahan pekerjaan dengan alasan adalah meningkatkan kemampuan, menerima imbalan secara moneter (gaji dan bonus), dan pengembangan diri (Yuen, 2016). Hal ini berbeda dengan Generasi Y di mana pada penelitian yang dilakukan oleh Anderson (Kurniawati dkk., 2012) menunjukkan bahwa satu dari empat Generasi Y akan keluar dari pekerjaannya pada tahun tertentu, dan keinginan keluar tersebut tiga kali lebih besar dibanding Generasi X.

Selain itu karakteristik karyawan generasi Y adalah rendahnya engagement pada perusahaan tempat mereka bekerja. Hal ini dibuktikan pada survei Gallup (2015 dalam Mann \& McCarville, 2015). Hasilnya sebanyak 51\% karyawan generasi Y di Amerika Serikat berpindah pekerjaan dengan alasan karena mencari kesempatan kerja yang lebih menarik. Survei pada Jobstreet.com di tahun 2016. Hasilnya menunjukkan bahwa 65,8\% dari 3,500 karyawan generasi Y di Indonesia berpindah pekerjaan secara sukarela dalam kurun waktu kurang dari 2 tahun (Suryaratri \& Abadi, 2018). Selain itu, survei yang dilakukan oleh Jobstreet Malaysia pada 1,181 perusahaan dan 2,426 karyawan di Malaysia. Tujuan dari survei tersebut yaitu mencari alasan kenapa karyawan meninggalkan perusahaan. Hasil yang ditunjukkan bahwa 81\% karyawan melakukannya karena ingin mendapatkan reward dan kompensasi yang lebih dan 31\% dari 2426 karyawan meninggalkan karena tidak ada perkembangan karir.

Salah satu yang menghambat komitmen di perusahaan adalah job hopping intention. Konsep job hopping telah dikaji oleh beberapa ahli. Konsep job hopping pertama kali dijelaskan oleh Ghiselli (1974 dalam (Yuen, 2016)) dimana pekerja cenderung untuk melakukan pergantian pekerjaan dalam kurun waktu yang cepat tanpa memiliki tujuan yang jelas. Hal ini dilakukan secara naluriah, sehingga perilaku ini disebut dengan hobo syndrome. Menurut Friedel dkk (2015 dalam Yuen, 2016) mendefinisikan job hopping adalah keluarnya karyawan dari pekerjaan disebabkan karena career advancement maupun untuk meningkatkan kesuksesan diri dalam berkarir. Hal serupa disampaikan oleh Yuen bahwa job hopping karyawan yang berganti pekerjaan atau berpindah ke perusahaan lain bertujuan untuk mendapatkan peningkatan dalam pengembangan diri maupun finansial (Yuen, 2016). Lalu, Pranaya mendefinisikan job hopping merupakan suatu pergantian pekerjaan yang dilakukan setelah mereka bekerja selama satu atau dua tahun bekerja atas keinginannya sendiri (Pranaya, 2014). 
Peningkatan job hopping pada pekerja Generasi Y disebabkan oleh berbagai alasan. Generasi Y melakukan job hopping karena mereka ingin bekerja di perusahaan maupun pekerjaan yang sesuai dengan preferensinya (contoh: mengutamakan kebebasan dan fleksibilitas dalam berkarir) dan mereka akan cenderung keluar dari pekerjaan jika pekerjaannya tidak sesuai dengan ekspektasinya (Yuen, 2016). Selain itu, terdapat dua motivasi pekerja untuk melakukan job hopping, pertama adalah the escape motivation dimana pekerja akan berganti pekerjaan untuk keluar dari lingkungan kerja yang membuatnya tidak nyaman. Motivasi kedua adalah the advancement motive, perilaku berganti pekerjaan sebagai sarana untuk meningkatkan karirnya.

Tidak hanya berdampak pada karyawan saja, perilaku job hopping dinilai sebagai isu bagi perusahaan yang ditinggalkan oleh karyawan yang melakukannya. Karyawan yang keluar dari pekerjaan dan berpindah ke perusahaan kompetitor menjadi sebuah ancaman bagi perusahaan. Hal ini dialami oleh perusahaan industri teknologi di Singapura yang khawatir jika karyawan akan menjelaskan informasi mengenai perkembangan teknologi ke perusahaan kompetitor (Yuen, 2016). Selain itu, karyawan di negara lain seperti Jerman, Jepang, dan Amerika memprotes karyawan yang berkemungkinan besar akan melakukan job hopping karena perusahaan kompetitor akan merekrut karyawan yang sudah diberi training (Suryaratri \& Abadi, 2018). Selanjutnya, perusahaan akan mengalami kerugian material atau separation cost di mana ketika karyawan yang berpengalaman meninggalkan perusahaan, maka perusahaan harus mengeluarkan biaya rekrutmen hingga training untuk mencari pengganti dari karyawan yang melakukan job hopping (Philip, 2017). Karyawan sering berganti pekerjaan akan menyebabkan seringnya kekurangan tenaga kerja di perusahaan, dan akan sangat mempengaruhi kemajuan perusahaan dan menghambat penyelenggaraan training yang akan diberikan pada karyawan baru (Yuen, 2016).

Job hopping dipengaruhi oleh faktor internal yaitu career adaptability. Career adaptability dapat berfungsi untuk membantu karyawan dalam menyesuaikan diri dengan lingkungan (perubahan dan tantangan) (Savickas, 1997). Di sisi lain career adaptability digunakan sebagai fasilitas untuk karyawan melakukan mobilitas karir (Ito \& Brotheridge, 2005). Career adaptability merupakan faktor yang paling dipertimbangkan saat menentukan apakah individu akan menetap atau meninggalkan pekerjaannya. Kemampuan career adaptability memiliki peran penting terhadap pekerja yang bekerja pada perusahaannya saat ini. Kemampuan tersebut dapat menentukan kecocokan antara mereka dengan pekerjaannya. Hal ini sesuai dengan karakteristik karyawan Generasi Y yaitu memilih pekerjaannya sesuai dengan preferensi pekerjaannya tersebut seperti kebebasan, tanggung jawab pekerjaan, dan lain sebagainya (Yuen, 2016). Peran lainnya adalah career adaptability dijadikan sebagai skill yang dapat memfasilitas pengembangan karir kedepan dan membantu beradaptasi dengan tanggung jawab (Haibo dkk., 2018).

Menurut teori konstruksi karir (Savickas, 1997; Savickas \& Porfeli, 2012), kemampuan beradaptasi karir menggambarkan berbagai sumber daya psikologis yang terlibat dalam proses pemecahan masalah dalam pengembangan karir seseorang, termasuk perhatian karir (kemampuan mempertimbangkan kemungkinan masa depan dan mempersiapkan kemungkinan ini), kontrol karir (kemampuan membuat keputusan yang disengaja dan mengambil tindakan dengan hati-hati), keingintahuan karir (kekuatan menjelajahi berbagai situasi dan peran), dan kepercayaan diri karir (keyakinan positif pada keterampilan pemecahan masalah seseorang di berbagai situasi). Untuk mengembangkan kemampuan adaptif ini, individu perlu terus-menerus mendapatkan wawasan tentang karakteristik mereka sendiri dan kompleksitas lingkungan kerja melalui berbagai pengalaman pribadi (Savickas \& Porfeli, 2012).

Penelitian lain menyatakan bahwa kemampuan career adaptability yang tinggi dinilai sebagai kemampuan eksplorasi diri dalam berbagai kemungkinan opsi dalam pekerjaan sehingga career 
adaptability membuat seseorang mempertimbang untuk meninggalkan pekerjaan dan/atau perusahaannya jika mempunyai opsi yang lebih baik di luar pekerjaan (Haibo dkk., 2018; Ito \& Brotheridge, 2005; Karatepe \& Olugbade, 2017). Sebaliknya ketika career adaptability dipersepsikan rendah membuat karyawan menjadi tidak mengeksplorasi diri dan berpeluang ke pekerjaan maupun tempat lainnya sehingga tidak memiliki keinginan untuk keluar dari pekerjaannya. Dari pemaparan tersebut dapat dilihat bahwa career adaptability mampu menghasilkan dua reaksi yang berbeda.

Berdasarkan perbedaan arah hubungan ini, peneliti menduga bahwa ada hal yang menjadi perantara di antara career adaptability terhadap job hopping intention, yaitu career satisfaction, adalah kepuasan karyawan dari aspek internal (kompensasi dan promosi) dan aspek eksternal (pengembangan dan pelatihan) pada karir seseorang (Greenhaus dkk., 1990). Beberapa penelitian menunjukkan bahwa seseorang yang puas dengan karirnya akan beradaptasi dengan lingkungan sehingga mengurangi seseorang untuk memiliki keinginan untuk berganti pekerjaan.

Career adaptability memiliki peran penting untuk memprediksi career satisfaction dan intensi untuk meninggalkan pekerjaannya (Haibo dkk., 2018). Karyawan yang memiliki kemampuan career adaptability yang tinggi maka akan meningkat pula career satisfaction sehingga ketika karyawan mengalami career satisfaction, maka keinginan untuk berpindah pekerjaan semakin berkurang (Chan \& Mai, 2015). Karyawan yang dapat beradaptasi dalam karirnya maka dapat berkontribusi dan menyelesaikan permasalahan yang ada di pekerjaannya. Ketika seseorang dapat menyelesaikan hal tersebut maka akan mendapat career satisfaction karena mereka mendapatkan prospek yaitu promosi, pengakuan, dan tunjangan lainnya. Hal ini didukung oleh (Savickas \& Porfeli, 2012), yang menjelaskan bahwa kapasitas karyawan untuk menyesuaikan diri dalam menghadapi tantangan di tempat kerja dapat meningkatkan sikap positif mereka terhadap karier mereka, sehingga dengan sikap positif yang dimiliki karyawan meningkat maka dapat career satisfaction individu.

Peneliti menduga bahwa hubungan career satisfaction dan job hopping intention melemah jika diiringi dengan career satisfaction. Hal ini berdasarkan pada teori konstruksi karir, menjelaskan bahwa sumber adaptabilitas dalam membantu untuk menyusun strategi yang digunakan oleh individu dengan tujuan agar dapat membentu perilaku adaptif di pekerjaannya. Career satisfaction berperan sebagai penghubung yang jelas pada hubungan career adaptability dan intensi berpindah pekerjaan sehingga karyawan dengan tingkat adaptasi karir yang tinggi lebih sensitif dan sejauh mana mereka memiliki peluang karir yang baik (Savickas \& Porfeli, 2012)

Berdasarkan penjelasan diatas dapat dilihat bahwa kemampuan career adaptability yang dimiliki oleh pekerja Generasi Y memiliki peran terhadap munculnya job hopping intention yang dimediasi oleh career satisfaction. Berikut adalah hipotesis dalam penelitian ini:

$\mathrm{H}_{1} \quad$ : Adanya berpengaruh secara signifikan antara career adaptability dan job hopping pada karyawan generasi Y.

$\mathrm{H}_{2} \quad$ : Adanya pengaruh secara signifikan antara career adaptability dan job hopping intention dengan career satisfaction (variabel mediator) pada karyawan generasi Y.

\section{Desain Penelitian}

\section{METODE}


Pendekatan penelitian kuantitatif menggunakan penelitian explanatory research (Neuman, 2014). Tipe penelitian tersebut dipilih karena tujuan penelitian yaitu mengenal lebih dalam mengenai pengaruh career adaptability terhadap job hopping intention dengan career satisfaction sebagai variabel mediator.

\section{Partisipan}

Penelitian membutuhkan partisipasi yaitu pekerja Generasi Y dengan usia antara 21-41 tahun, serta pekerja full time yang sudah bekerja selama kurang dari 2 tahun. Dalam penelitian, peneliti memilih non-probability sampling dan purposive sampling sebagai teknik penelitian (Neuman, 2014). Dalam menentukan sampel, penulis mengacu pada pedoman Pallant (2001). untuk menentukan jumlah minimal sampel dengan rumusan $\mathrm{N}>50+8 \mathrm{~m}$. Berdasarkan perhitungan menggunakan rumus tersebut, maka jumlah minimal sampel yang digunakan sejumlah 66 partisipan. Data yang terkumpulkan menggunakan metode survei atau kuesioner (Neuman, 2014). Setelah menyebarkan kuesioner, penulis mendapatkan partisipan sejumlah 117 pekerja Generasi Y.

\section{Pengukuran}

Variabel career adaptability menggunakan alat ukur Career Adaptability Scale (CAAS) form 2.0 yang disusun oleh (Savickas \& Porfeli, 2012) dan telah diadaptasi ke bahasa Indonesia oleh Giffari \& Suhariadi (2017). Skala ini disusun berdasarkan empat dimensi career adaptability seperti control, concern, curiosity, dan career confidence. CAAS diukur dengan likert scale yaitu $1=$ tidak kuat sampai $5=$ paling kuat, dengan reliabilitas yang cukup baik $(\alpha=.835)$. Alat ukur yang digunakan pada career satisfaction adalah Career Satisfaction Scale yang dikembangkan oleh Greenhaus dkk. (1990). Skala ini memiliki total 5 aitem yang berisi tingkat kepuasan karyawan terhadap beberapa aspek dalam karirnya, seperti kepuasan secara keseluruhan, promosi, pengembangan dan keterampilan, dan pendapatan yang diterima. Sistem penilaian menggunakan likert scale dengan skala angka 1 = sangat tidak puas hingga 5 = sangat puas, dengan reliabilitas yang cukup baik $(\alpha=.838)$. Alat ukur yang digunakan pada job hopping intention adalah Job Hopping Intention Scale dengan likert scale yaitu skala angka $1=$ sangat tidak puas hingga 5 = sangat puas.

\section{Analisis Data}

Sebelum melakukan analisis data regresi, penulis menguji uji asumsi seperti uji normalitas, linieritas, dan homokedastisitas melalui bantuan program IBM SPSS 25.0 untuk Windows. Kemudian untuk mengetahui peran mediasi career satisfaction antara career adaptability dengan job hopping intention menggunakan sobel test.

\section{HASIL PENELITIAN}

\section{Analisis Deskriptif}

Salah satu analisis bertujuan untuk menganalisis melalui memberi deskripsi terkait karakteristik sampel yang digunakan dalam penelitian dan hanya berhubungan dengan memberikan hasil analisis berdasarkan data (Pallant, 2001). Analisis deskriptif meliputi jumlah responden, mean, dan standar deviasi (SD), nilai minimal (Min), dan nilai maksimal (Max).

Data penelitian yang dapat diolah dalam penelitian yaitu sejumlah 107 partisipan. Dari proses oleh data, diketahui bahwa variabel career adaptability memiliki nilai $(M=101,19 ; S D=10,22 ;$ Min= 72; $\operatorname{Max}=120)$. Kemudian untuk variabel career satisfaction memiliki nilai $(M=17,86 ; S D=3,51 ; \operatorname{Min}=9$; $\operatorname{Max}=25)$. 
Kemudian untuk variabel job hopping intention diketahui memiliki nilai $(M=11,37 ; S D=10,22 ;$ Min= 4; $M a x=20)$.

\section{Analisis Regresi}

Dalam analisis regresi, diperoleh data $\left(F(1,105)=0,230 ; p=0,633 ; R^{2}=0.002\right)$. Career adaptability menjelaskan sebanyak 0,2 \% dalam job hopping intention. Career adaptability $(B=0,019 ; S E=0,039$; $t=0,479 ; p=0,633$ ) tidak berpengaruh terhadap job hopping intention.

Selain itu, data analisis regresi antara career adaptability terhadap career satisfaction yaitu $(F(1$, 105) $\left.=19,391 ; p=0,000 ; R^{2}=0.156\right)$. Career adaptability menjelaskan sebanyak 15,6 \% dalam job hopping intention. Career adaptability $(B=-0,455 ; S E=0,103 ; t=-4,404 ; p=0,000)$ berpengaruh negatif dan signifikan terhadap career satisfaction.

Data analisis regresi antara career satisfaction terhadap job hopping intention yaitu $(F(1,105)=13,994$; $p=0,000 ; R^{2}=0.118$ ). Career satisfaction menjelaskan sebanyak $11,8 \%$ dalam job hopping intention. Career satisfaction $(B=0,118 ; S E=0,032 ; t=3,41 ; p=0,000)$ berkorelasi positif dan signifikan terhadap job hopping intention.

\section{Analisis Sobel Test}

Untuk menguji peran career satisfaction sebagai mediator pada pengaruh career adaptability terhadap job hopping intention, peneliti menggunakan sobel test. Berdasarkan hasil sobel test, diketahui data $(Z=$ -3.610; $\mathrm{SE}=0.037 ; p=0.000$ ) menunjukkan bahwa pengaruh tidak langsung antara career adaptability dan job hopping bersifat signifikan ketika career satisfaction dilibatkan.

\section{DISKUSI}

Penelitian ini memiliki salah satu hipotesis, yaitu tidak ada pengaruh career adaptability dan job hopping intention. Hasil ini sejalan dengan hasil penelitian Karatepe pada pekerja front-line hotel di bidang mesin di Nigeria (Karatepe \& Olugbade, 2017). Karatepe menjelaskan bahwa tidak adanya hubungan career adaptability dan job hopping intention karena career adaptability dinilai sebagai kemampuan problem solving untuk permasalahan yang dihadapi sehari-hari sehingga tidak memungkinkan untuk karyawan untuk pindah pekerjaan. Hal ini senada dengan penelitian Santra yang menjelaskan bahwa karyawan IT di India akan meninggalkan pekerjaan jika mereka mendapatkan peluang yang tepat dan memikirkan masa depannya (Santra \& Giri, 2019).

Faktor pertama yang menyebabkan gagalnya pembuktikan $\mathrm{H}_{1}$ adalah adanya negativity bias. Negativity bias adalah ketika dalam banyak situasi, peristiwa negatif cenderung kuat, menonjol, dan dominan dibanding peristiwa positif dengan besaran tujuan yang sama, peristiwa negatif secara subjektif lebih kuat, dan lebih menonjol daripada pasangannya, yaitu peristiwa positif. Stimulus negatif akan lebih berpengaruh secara tidak proposional dalam menentukan keseluruhan penilaian terhadap suatu dibanding stimulus positif. Dalam penelitian ini diasumsikan bahwa peristiwa negatif adalah tingginya job hopping intention, sedangkan peristiwa positif adalah tingginya tingkat career satisfaction. Hal inilah yang dapat menyebabkan $\mathrm{H}_{1}$ ditolak. Seberapapun tinggi career adaptability tidak berpengaruh pada job hopping intention. Karena, individu lebih berfokus pada penilaian bersifat negatif.

Faktor kedua adalah terdapat hal lain yang lebih mendominasi penyebab munculnya job hopping intention, dari hasil uji regresi berganda yang dilakukan peneliti, didapatkan hasil bahwa model regresi

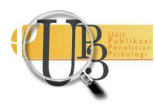


dengan career adaptability dan job hopping intention memiliki sumbangan efektif yang cukup kecil, yaitu $2 \%$ saja $\left(\mathrm{r}^{2}=0,002\right)$. Dari sini dapat dilihat bahwa masih ada $98 \%$ sumbangan efektif yang berasal dari variabel lainnya yang mampu menjelaskan variabel job hopping intention pada konteks pekerja Generasi Y secara lebih baik.

Sehingga, dalam penelitian ini dapat diimplementasikan bahwa career adaptability dipersepsikan sebagai kemampuan eksplorasi diri oleh karyawan yang bekerja dibawah dua tahun dan seberapapun tinggi tingkat career satisfaction mempengaruhi hubungan antara career adaptability dan job hopping intention.

\section{SIMPULAN}

Berdasarkan hasil analisis data, disimpulkan bahwa career satisfaction dapat full-mediated pada pengaruh career adaptability terhadap job hopping intention pada karyawan millennials, sehingga $\mathrm{H}_{2}$ diterima. Berdasarkan hasil penelitian yang didapat, perusahaan perlu merencanakan strategi agar mencegah karyawan untuk melakukan job hopping. Berikut strategi yang bisa dilakukan adalah career adaptability dapat dikembangkan seperti pada career concern ditingkatkan dengan kegiatan pengenalan perusahaan, career control dikembangkan dengan pelatihan untuk membuat keputusan, career confidence ditingkatkan melalui kegiatan mencari informasi mengenai tugas dan tantangan di dalam pekerjaan, dan career confidence dapat dikembangan melalui pembangunan self-esteem yang dimiliki oleh karyawan karyawan yang dapat memanfaatkan career adaptability dalam berbagai situasi

Berdasarkan kesimpulan yang diperoleh, berikut ini saran-saran untuk penelitian selanjutnya adalah career satisfaction dapat memediasi pengaruh career adaptability terhadap job hopping intention sehingga bisa menggunakan variabel berbeda seperti komitmen organisasi dan work social support.

\section{UCAPAN TERIMAKASIH}

Terima kasih kepada pihak-pihak yang berperan besar antara lain dosen pembimbing, dosen penguji dan segenap civitas akademik Fakultas Psikologi Universitas Airlangga yang telah membantu tercapainya penelitian ini, serta partisipan-partisipan yang bersedia untuk mengisi kuesioner penelitian sehingga bisa menyelesaikan dengan tuntas.

\section{DEKLARASI POTENSI TERJADINYA KONFLIK KEPENTINGAN}

Sekar Hanum Prihaningrum dan Herison Pandapotan Purba tidak bekerja, menjadi konsultan, memiliki saham, atau menerima dana dari perusahaan atau organisasi manapun yang mungkin akan mengambil untung dari diterbitkannya naskah ini.

\section{PUSTAKA ACUAN}

Chan, S. H. J., \& Mai, X. (2015). The relation of career adaptability to satisfaction and turnover intentions. Journal of Vocational Behavior, 89, 130-139. https://doi.org/10.1016/j.jvb.2015.05.005 
Giffari, N., \& Suhariadi, F. (2017). Pengaruh Social Support Terhadap Creer Adaptability Pada Mahasiswa Tingkat Akhir Fakultas Psikologi Universitas Airlangga. Jurnal Psikologi Dan Organisasi, 6(4), 6477. https://journal.unair.ac.id/JPIO@pengaruh-social-support-terhadap-career-adaptabilitypada-mahasiswa-tingkat-akhir-fakultas-psikologi-universitas-airlangga-article-12547-media-50category-10.html

Greenhaus, J. H., Parasuraman, S., \& Wormley, W. M. (1990). Effects Of Race On Organizational Experiences, Job Perform. Academy of Management Journal, 33(1), 64.

Guha, A. B. (2010). Motivators and Hygiene Factors of Generation X and Generation Y-The Test of TwoFactor Theory. The XIMB Journal of Management. Sep2010, 7(2), 121-132. 12p. 1 Diagram.

Haibo, Y., Xiaoyu, G., Xiaoming, Z., \& Zhijin, H. (2018). Career Adaptability With or Without Career Identity: How Career Adaptability Leads to Organizational Success and Individual Career Success? Journal of Career Assessment, 26(4), 717-731. https://doi.org/10.1177/1069072717727454

Holyoke, L., \& Larson, E. (2009). Engaging the adult learner generational mix. Journal of Adult Education, $38(1), 12-21$.

Ito, J. K., \& Brotheridge, C. M. (2005). Does supporting employees' career adaptability lead to commitment turnover, or both? Human Resource Management, 44(1), 5-19. https://doi.org/10.1002/hrm.20037

Karatepe, O. M., \& Olugbade, O. A. (2017). The effects of work social support and career adaptability on career satisfaction and turnover intentions. Journal of Management and Organization, 23(3), 337355. https://doi.org/10.1017/jmo.2016.12

Kurniawati, F., Minnaert, A., Mangunsong, F., \& Ahmed, W. (2012). Empirical Study on Primary School Teachers' Attitudes Towards Inclusive Education in Jakarta, Indonesia. Procedia - Social and Behavioral Sciences, 69(Iceepsy), 1430-1436. https://doi.org/10.1016/j.sbspro.2012.12.082

Luntungan, I. I., Hubeis, A. V. S., Sunarti, E., \& Maulana, A. (2014). Strategi Pengelolaan Generasi Y di Industri Perbankan. Jurnal Manajemen Teknologi, 13(2), 219-240. https://doi.org/10.12695/jmt.2014.13.2.7

Mahmoud, A. B., Fuxman, L., Mohr, I., Reisel, W. D., \& Grigoriou, N. (2021). “We aren't your reincarnation!" workplace motivation across X, Y and Z generations. International Journal of Manpower, 42(1), 193-209. https://doi.org/10.1108/IJM-09-2019-0448

Mann, A., McCarville, B. (2015). What Job-Hopping Employees Are Looking For. Gallup. http://www.gallup.com/businessjournal/186602/jobhoppingemployeeslooking.\%5Cnaspx?vers ion=print

Neuman, W. L. (2014). Basics of Social Research.

Omar, S., \& Tajudeen, F. P. (2020). The Influence of Career Adaptability and Career Commitment to Minimize Intention to Leave Among ICT Professionals. In International Journal of Human Capital and Information Technology Professionals (Vol. 11, Issue 2, pp. 23-38).

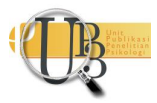


https://doi.org/10.4018/ijhcitp.2020040102

Pallant, J. (2001). SPSS Survival Manual: A Step by Step Guide to Data Analysis Using Spss for Windows. 287.

Philip, N. (2017). Job-Hopping: Does it benefit or detriment careers? A study of the careers of HRS alumni. February, 1-59. http://arno.uvt.nl/show.cgi?fid=145778

Pranaya, D. (2014). Job-hopping - An Analytical Review. International Journal of Research in Business Management, 2(4), 2321-2886. www.impactjournals.us

Santra, S., \& Giri, V. N. (2019). Role of Career Adaptability and Its Resources in Predicting Vocational Attitudes of Indian IT Professionals. Management and Labour Studies, 44(2), 168-192. https://doi.org/10.1177/0258042x18822564

Savickas, M. L. (1997). Career adaptability: An integrative construct for life-span, life-space theory. Career Development Quarterly, 45(3), 247-259. https://doi.org/10.1002/j.21610045.1997.tb00469.x

Savickas, M. L., \& Porfeli, E. J. (2012). Career Adapt-Abilities Scale: Construction, reliability, and measurement equivalence across 13 countries. Journal of Vocational Behavior, 80(3), 661-673. https://doi.org/10.1016/j.jvb.2012.01.011

Suryaratri, R. D., \& Abadi, M. A. (2018). Modal Psikologis dan Intensi Job Hopping pada Pekerja Generasi Millenial. Ikraith-Humaniora, 2(2), 77-83.

Yuen, S. H. (2016). Examining the generation effects on job-hopping intention by applying the Theory of Planned Behavior (TPB). 115. 